\title{
Microcytosis, iron deficiency, and thalassaemia in preschool children
}

\author{
A Earley, H B Valman, D G Altman, M J Pippard
}

\begin{abstract}
To investigate the possible causes of an increased incidence of red cell microcytosis in Asian children, 204 Gujarati Asian children and 88 European children attending community infant welfare clinics underwent initial screening tests for determination of red cell indices. Seventy six Asian (37\%) and nine European (12\%) children had microcytic red cells (mean corpuscular volume $<74 \mathrm{fl}$ ). Further investigation showed that 16 of the Asian children (21\%) with microcytosis had thalassaemia trait (eight were heterozygous for $\alpha$ thalassaemia and eight for $\beta$ thalassaemia), and $50(66 \%)$ had suspected iron deficiency (confirmed by a response to oral iron in 41 cases): the remaining 'microcytic' children were aged less than 2 years, when mean corpuscular volume between 70 and $74 \mathrm{fl}$ may be normal. Increased values for serum total iron binding capacity were more sensitive in detecting iron deficiency than reduced serum ferritin concentrations. Enthusiastic screening for microcytic anaemia in young children may mean that a substantial minority with thalassaemia genes are given unnecessary iron supplements. The response to a short course of oral iron should therefore be carefully monitored, and the possibility of thalassaemia trait as well as non-compliance with treatment should be reconsidered in all those in whom there is little or no response.
\end{abstract}

A reduction in the size of red cells (microcytosis) has been reported more often in Asian than in European children of the same age in both community $^{1}$ and hospital ${ }^{2}$ studies. This finding has been attributed to a high incidence of dietary iron deficiency in Asian children, although heterozygous $\beta$ thalassaemia is a potential additional cause. ${ }^{2} 3$ Previous studies have not considered the possibility that $\alpha$ thalassaemia genes, which occur commonly in some groups, ${ }^{4}$ contribute to the observed reduction in red cell size. This is an important consideration, as there is increasing pressure to identify and treat iron deficiency in young children. ${ }^{5}$ This reflects growing concern about the possible non-haematological effects of a low iron concentration, even without obvious anaemiaespecially the deleterious effects on learning ability. ${ }^{6-8}$ Without a therapeutic trial of iron, mild degrees of iron deficiency may be difficult to confirm in young children who have little or no iron stores, 910 and in whom serum iron and transferrin saturation are significantly lower than in adults. ${ }^{11}$ Microcytosis thus assumes added importance for suspecting iron deficiency in young children, but may lead to unnecessary treatment with iron supplements if there is a high incidence of unrecognised $\alpha$ thalassaemia in the population.

In this community based study we have examined the relative contributions made by iron deficiency and thalassaemia genes, especially $\alpha$ thalassaemia trait, to microcytosis in a predominantly Hindu, Gujarati Asian population, compared with European children from the same area of north west London.

Subjects and methods

PLAN OF INVESTIGATION AND TREATMENT

Venous blood samples of $5 \mathrm{ml}$ or less were taken from 204 Asian and 88 European children after informed consent from a parent. All were apparently healthy children attending infant welfare clinics in Harrow for routine immunisation or developmental screening, and were aged between 6 months and 6 years. The children were recruited consecutively as they came to the clinic, excluding those whose parents did not want them to take part. We also excluded those who were taking preparations containing iron, and those who had febrile illnesses. Details of racial origin and whether the child's family was vegetarian were recorded. All samples were taken between 1000 and 1300 , and were analysed the same day for haemoglobin concentration and red cell indices (Coulter S+IV), and within three days for serum iron and transferrin concentrations. Serum samples were stored at $-20^{\circ} \mathrm{C}$ for measurement of ferritin.

Microcytosis was defined as a mean corpuscular volume of $<74 \mathrm{fl}$ based on the lower limit for the mean cell volume reference range (mean (2 SD)) defined by Isaacs et al in a study of European children from the same locality. ${ }^{1}$ It was recognised that this cut off value would include a small number of normal, mainly young children, as the mean cell volume and haemoglobin concentrations increase slightly during early childhood. ${ }^{12}$ Because the haematological findings of $\alpha$ thalassaemia trait overlap with normal when only one of the four genes is deleted or non-functioning, we might have underestimated the prevalence of $\alpha$ thalassaemia by as much as $50 \%$ (DJ Higgs, personal communication).

If the mean cell volume was $<74 \mathrm{fl}$, haemoglobin $(\mathrm{Hb}) \mathrm{A}_{2}$ was estimated; $\beta$ thalassaemia trait was diagnosed if the percentage of $\mathrm{HbA}_{2}$ was greater than $3 \cdot 5$.

In microcytic patients, iron deficiency was suspected if iron stores seemed to be lacking, as 
shown by serum ferritin of $<16 \mu \mathrm{g} / \mathrm{l}$ or total iron binding capacity of $>90 \mu \mathrm{mol} / 1$, or both, or if there was evidence of reduced iron supply shown by a transferrin saturation of $<16 \%$. $^{13}$ Microcytic children with suspected iron deficiency were offered oral iron supplements (3-4 $\mathrm{mg} / \mathrm{kg}$ elemental iron as ferrous fumarate syrup) for 2-3 months, after which the blood test was repeated. The response to iron was considered to confirm iron deficient erythropoiesis if the mean corpuscular volume increased by at least $5 \mathrm{fl}$ or to $>74 \mathrm{fl}$.

Those microcytic children who had normal $\mathrm{HbA}_{2}$ and no evidence of iron deficiency on their initial sample, or whose mean corpuscular volume did not show a complete response to oral iron (mean corpuscular volume $>74 \mathrm{fl}$ ) had a further sample of blood taken for $\alpha$ globin gene mapping.

MEASUREMENTS OF IRON

Serum iron was measured by the guanidine/

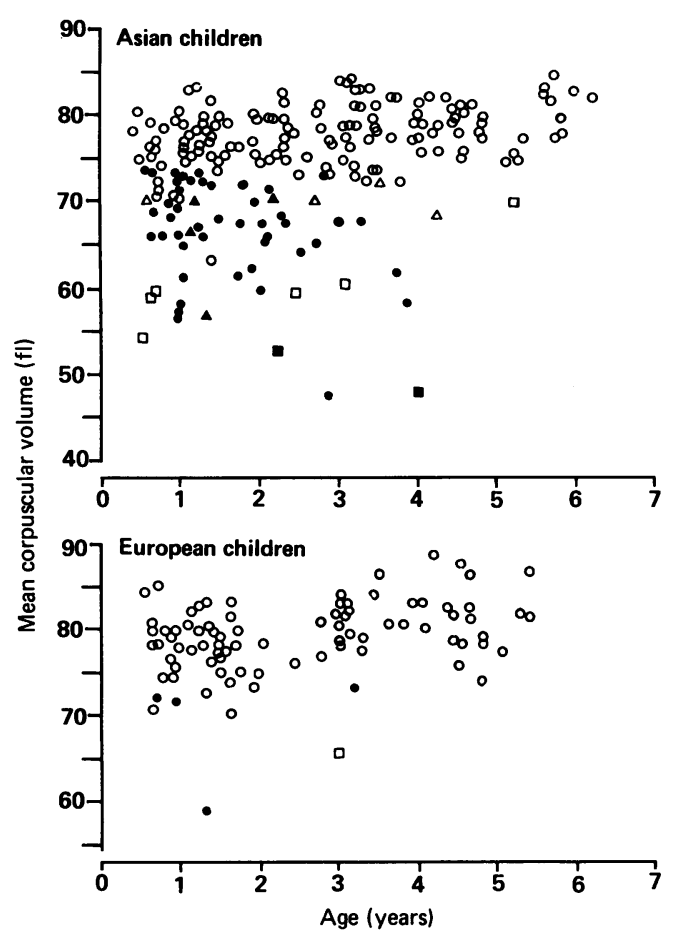

Figure 1 Red cell mean corpuscular volume in relation to age in Asian ( $n=204)$ and European $(n=88)$ children; $\triangle \alpha$ thalassaemia trait, $\Delta \alpha$ thalassaemia trait and iron deficiency, $\square \beta$ thalassaemia trait, $\square \beta$ thalassaemia trait and iron deficiency, O no confirmed abnormality, and iron deficiency. ferro zinc method (Radio Diagnostics). Serum transferrin was measured by a direct immunoturbidometric assay using antibody to human transferrin ${ }^{14}$; protein values were converted to total iron binding capacity using the slope of a linear regression plot of transferrin against total iron binding capacity based on 145 samples. Serum ferritin was measured by radioimmunoassay (Ferritin RIA kit, Amersham).

\section{THALASSAEMIA STUDIES}

Haemoglobin $A_{2}$ was measured by elution after electrophoresis with cellulose acetate. ${ }^{15} \alpha$ Globin gene mapping was done with restriction endonuclease analysis of DNA prepared from the buffy coat of heparinised blood. ${ }^{16}$

\section{STATISTICAL ANALYSIS}

The $\mathrm{p}$ values were calculated using the MannWhitney test, as data for some of the variables were skewed.

\section{Results}

\section{PATIENT CHARACTERISTICS}

Of the 204 Asian children, 106 were boys and 98 girls. The 88 European children comprised 52 boys and 36 girls. The Asian group was mainly of east African Gujarati origin, and $154(75 \%)$ were vegetarian, as were $12(14 \%)$ of the European children.

\section{MICROCYTOSIS}

Reduced mean corpuscular volume $(<74 \mathrm{fl})$ was more common among Asian children, being found in 76 of 204 (37\%) compared with nine of 88 (11\%) European children, and occurred more frequently among children under 3 years old (fig 1).

\section{HAEMOGLOBIN}

The mean (SD) haemoglobin concentration for the Asian children $(116.0(10 \cdot 1) \mathrm{g} / \mathrm{l})$ was slightly lower than for the European group (120.4 (7.0) $\mathrm{g} / \mathrm{l})$. In children who did not have microcytosis the haemoglobin concentrations were similar in Asian (120.0 (7.4) $\mathrm{g} / \mathrm{l})$ and European (121.0 $(7 \cdot 9) \mathrm{g} / \mathrm{l})$ children (table). In children with microcytosis, whether it was associated with confirmed iron deficiency or a thalassaemia trait, haemoglobin concentrations were generally lower than in non-microcytic children, but there was a considerable overlap (fig 2).

Measurements of iron absorption in Asian and European children excluding 16 Asian children with proved $\alpha$ or $\beta$ thalassaemia trait, and one European child with $\beta$ thalassaemia trai

\begin{tabular}{|c|c|c|c|c|c|c|c|c|c|c|}
\hline & \multicolumn{5}{|c|}{ Asian children } & \multicolumn{5}{|c|}{ European children } \\
\hline & \multicolumn{2}{|c|}{$\begin{array}{l}\text { Mean corpuscular } \\
\text { volume }<74 \mathrm{fl} \\
(\mathrm{n}=60)\end{array}$} & \multicolumn{2}{|c|}{$\begin{array}{l}\text { Mean corpuscular } \\
\text { volume }>74 \mathrm{fl} \\
(\mathrm{n}=128)\end{array}$} & \multirow[t]{2}{*}{$\stackrel{p}{\text { Value }}$} & \multicolumn{2}{|c|}{$\begin{array}{l}\text { Mean corpuscular } \\
\text { volume }<74 \mathrm{fl} \\
(\mathrm{n}=10)\end{array}$} & \multicolumn{2}{|c|}{$\begin{array}{l}\text { Mean corpuscular } \\
\text { volume }>74 f l \\
(n=77)\end{array}$} & \multirow[t]{2}{*}{$\stackrel{p}{\text { Value }}$} \\
\hline & Mean & $S D$ & Mean & $S D$ & & Mean & $S D$ & Mean & $S D$ & \\
\hline $\begin{array}{l}\text { Haemoglobin }(g / 1) \\
\text { Serum iron }(\mu \mathrm{mol} / \mathrm{l}) \\
\text { Total iron binding }\end{array}$ & $\begin{array}{r}109 \cdot 5 \\
7 \cdot 6\end{array}$ & $\begin{array}{r}11 \cdot 1(60) \\
5 \cdot 2(58)\end{array}$ & $\begin{array}{r}120 \cdot 0 \\
12 \cdot 8\end{array}$ & $\begin{array}{l}7 \cdot 4(128) \\
5 \cdot 7(121)\end{array}$ & $\begin{array}{l}<0.0001 \\
<0.0001\end{array}$ & $\begin{array}{r}115 \cdot 7 \\
9 \cdot 2\end{array}$ & $\begin{array}{l}7 \cdot 2(10) \\
4 \cdot 9(9)\end{array}$ & $\begin{array}{r}121 \cdot 0 \\
13 \cdot 7\end{array}$ & $\begin{array}{l}7 \cdot 9(77) \\
6 \cdot 7(66)\end{array}$ & $\begin{array}{l}0.04 \\
0.06\end{array}$ \\
\hline $\begin{array}{l}\text { capacity }(\mu \mathrm{mol} / \overline{1}) \\
\text { Saturation of total iron }\end{array}$ & $92 \cdot 8$ & $11 \cdot 0(56)$ & $79 \cdot 4$ & $9 \cdot 7(115)$ & $<0.0001$ & $78 \cdot 0$ & $14 \cdot 8(9)$ & $71 \cdot 3$ & $11 \cdot 5(66)$ & $0 \cdot 20$ \\
\hline $\begin{array}{l}\text { binding capacity (\%) } \\
\text { Ferritin }(\mu \mathrm{g} / \mathrm{l})\end{array}$ & $\begin{array}{r}8 \cdot 3 \\
20 \cdot 3\end{array}$ & $\begin{array}{r}5 \cdot 9(56) \\
15 \cdot 6(54)\end{array}$ & $\begin{array}{l}15 \cdot 9 \\
28 \cdot 7\end{array}$ & $\begin{array}{r}6 \cdot 8(115) \\
16 \cdot 4(112)\end{array}$ & $\begin{array}{l}<0.0001 \\
<0.0001\end{array}$ & $\begin{array}{l}12 \cdot 8 \\
11 \cdot 0\end{array}$ & $\begin{array}{l}8 \cdot 0(9) \\
4 \cdot 1(5)\end{array}$ & $\begin{array}{l}19 \cdot 2 \\
22 \cdot 0\end{array}$ & $\begin{array}{r}9 \cdot 5(65) \\
14.7(37)\end{array}$ & $\begin{array}{l}0.07 \\
0.09\end{array}$ \\
\hline
\end{tabular}

No of children in whom results of tests available given in parentheses. 


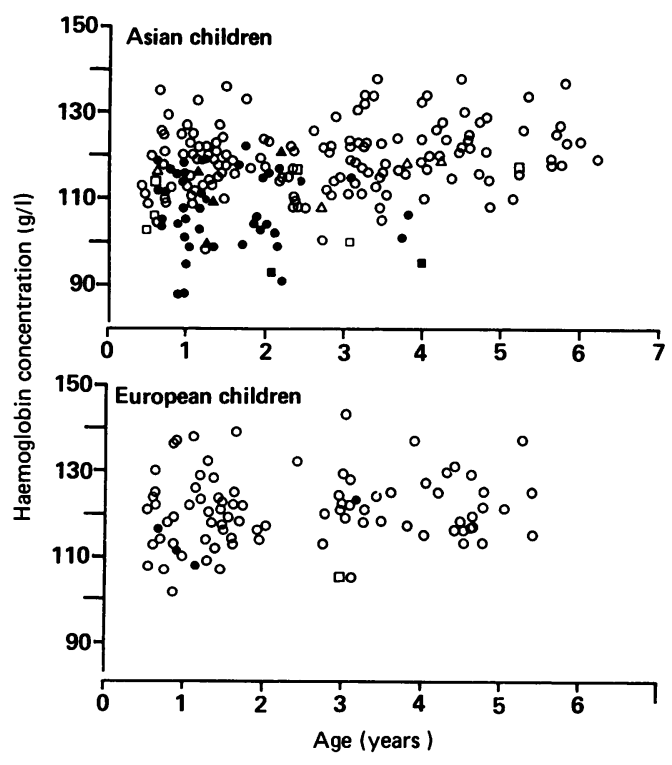

Figure 2 Haemoglobin concentration in relation to age in Asian $(n=204)$ and European $(n=88)$ children;

$\triangle \alpha$ thalassaemia trait, $\Delta \alpha$ thalassaemia trait and iron deficiency, $\square \beta$ thalassaemia trait, $\square \beta$ thalassaemia trait and iron deficiency, $\bigcirc$ no confirmed abnormality, and

iron deficiency.

\section{IRON ABSORPTION}

Serum ferritin and serum iron concentrations were generally lower, and total iron binding capacity was higher, in Asian and European children with microcytic red cells. Even when children who were later shown to be heterozygous for $\alpha$ or $\beta$ thalassaemia were excluded, however, there was considerable variability in these values (table). In the Asian children, nonthalassaemic microcytosis was more consistently associated with an increased serum total iron binding capacity of $>90 \mu \mathrm{mmol} / 1$ than a subnormal $(<16 \mu \mathrm{g} / \mathrm{l})$ serum ferritin concentration (fig 3). Children who were not microcytic were not offered iron supplements, but 45 Asian children with a mean corpuscular volume of $>74 \mathrm{fl}$ showed biochemical evidence of absent iron stores or reduced tissue iron supply, or both.

\section{CAUSES OF MICROCYTOSIS}

In 50 of 76 microcytic Asian children the tests of iron absorption led to a suspicion of iron deficiency and the offering of oral iron supplements (fig 4). Of these, 41 responded by increasing their mean corpuscular volume by $5 \mathrm{fl}$ or more, or to $>74 \mathrm{fl}$. Two of these responders had $\beta$ thalassaemia trait as well as iron deficiency, and in four responders in whom the mean corpuscular volume remained below $74 \mathrm{fl}$, deletional $\alpha$ thalassaemia trait was later shown. Of the nine non-responders, seven children were thought not to have taken the iron supplements regularly, and in two (mean corpuscular volume 66 fl and $70 \mathrm{fl}$, respectively) no cause was found. Their $\alpha$ gene maps were normal, and further studies of globin chain synthesis were inconclusive, failing to confirm a non-deletional $\alpha$ thalassaemia trait. ${ }^{17}$

Twenty six Asian children were not offered iron. The low mean corpuscular volume was caused by $\alpha$ thalassaemia trait in four subjects and $\beta$ thalassaemia trait in six. Six further children may have had iron deficiency, but there were incomplete data on iron values and no therapeutic trial of oral iron. Ten children with small red cells had normal iron and $\mathbf{H b A}_{2}$ values, and $\alpha$ gene mapping: they were all aged $<2$ years, had mean corpuscular volumes in the range $70-74 \mathrm{fl}$, and were thought to be normal. ${ }^{12}$ Overall, $20 \%$ of Asian children had confirmed microcytosis and iron deficiency. Iron deficiency was suspected, but not proved, as the cause of microcytosis in a further $6 \%$. If the non-microcytic children who showed some biochemical evidence of iron deficiency were included the combined incidence of confirmed and possible iron deficiency rises to $48 \%$.

A total of 42 children underwent $\alpha$ globin gene mapping. The incidence of single gene deletion $\alpha$ thalassaemia trait $(\alpha-/ \alpha \alpha)$ in this Asian population was $4 \%$. In addition, two children had triplicated $\alpha$ genes on one chromosome $(\alpha \alpha \alpha / \alpha \alpha){ }^{18}$ The incidence of $\beta$ thalassaemia was also $4 \%$.

Nine European children had mean corpus-
Figure 3 Distribution of measures of iron absorption in Asian children excluding those with proved $\alpha$ or $\beta$ thalassaemia trait; $A, B$, and $C$ are children with a mean corpuscular volume of $>74$ fl and $D, E$, and $F$ children with a mean corpuscular volume of $<74 \mathrm{fl}$ TIBC is total iron binding capacity.
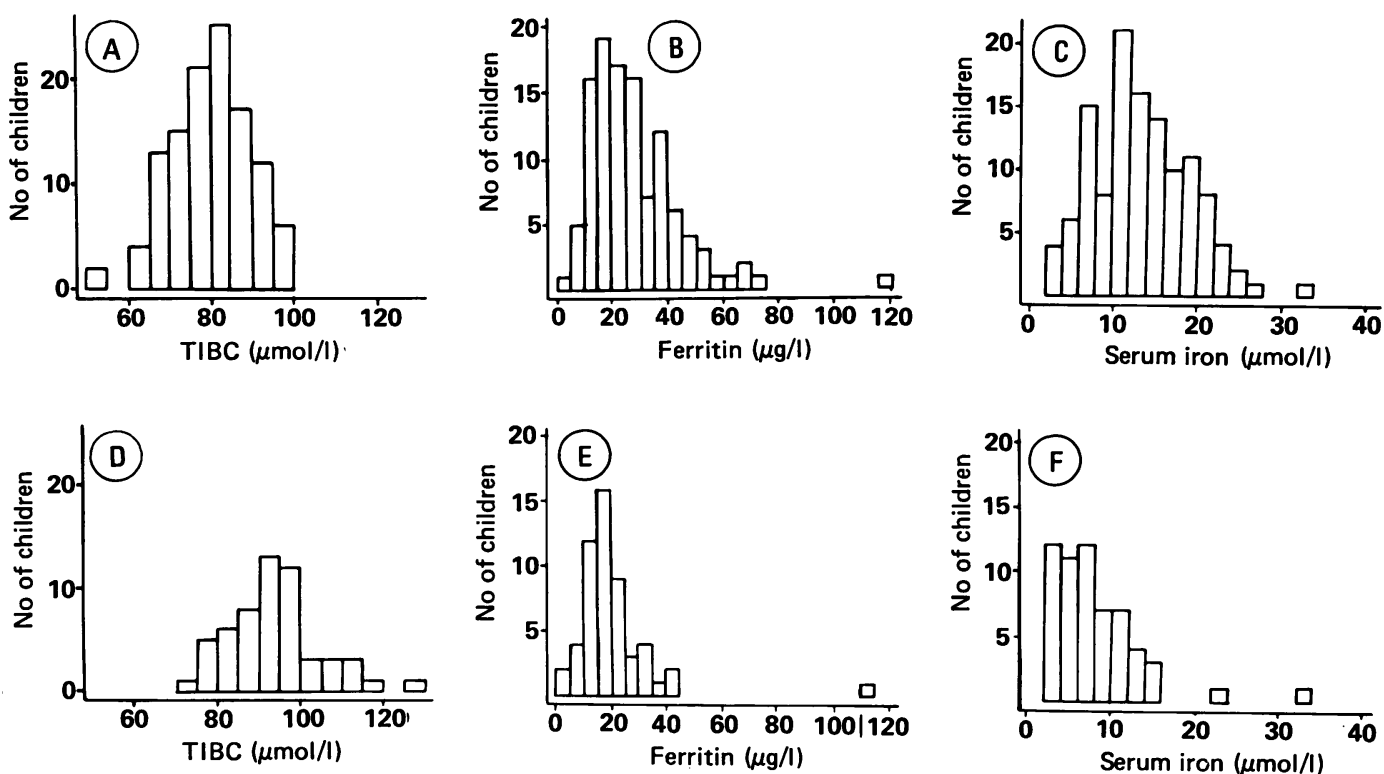
Figure 4 Flow diagram indicating results of investigations.in Asian children; numbers of children are given in parentheses. * Four children also had $\alpha$ thalassaemia trait and two also had $\beta$ thalassaemia trait.

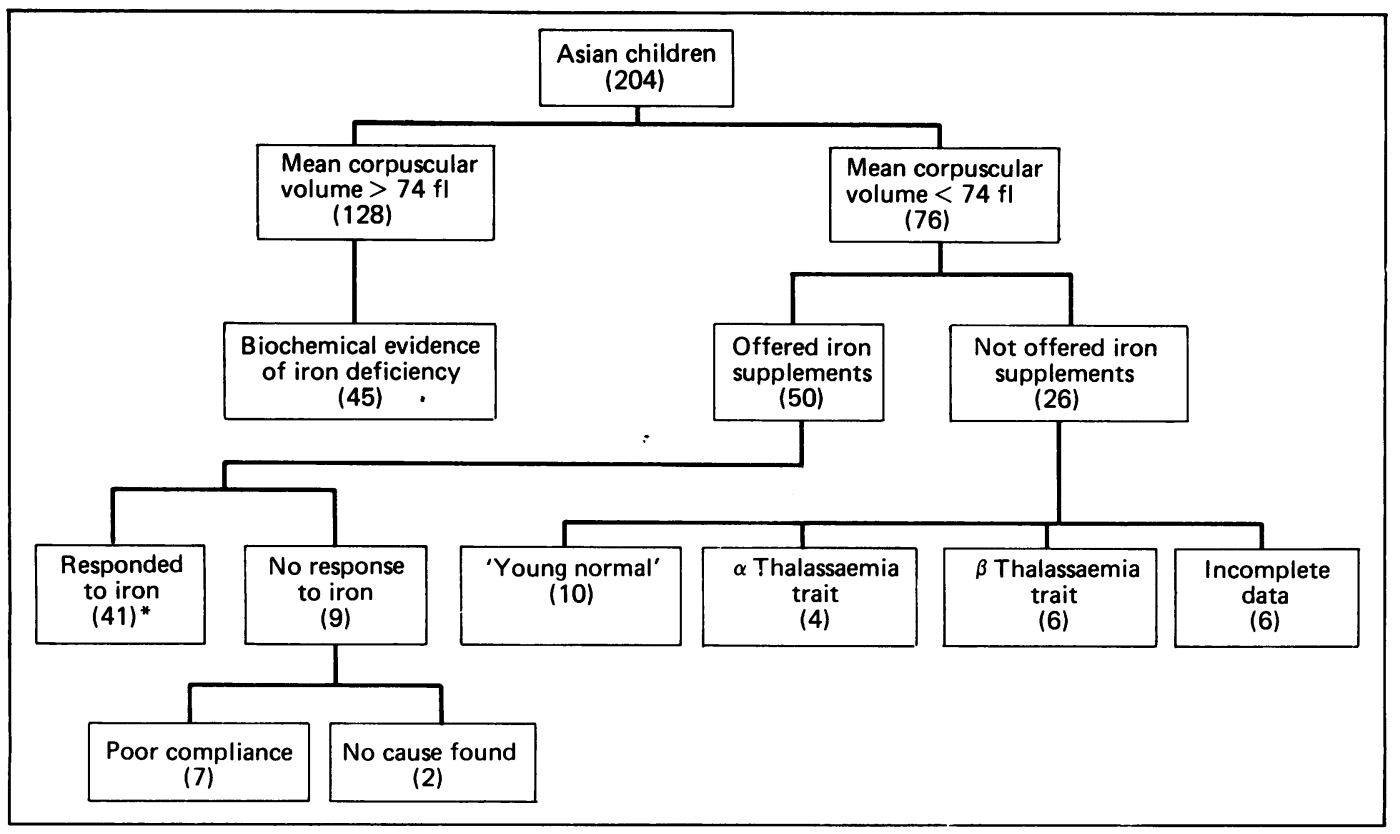

cular volumes of $<74 \mathrm{fl}$. Four were confirmed as iron deficient, one carried $\beta$ thalassaemia trait (one Greek parent) and four were normal children aged $<2$ years.

\section{Discussion}

Iron deficiency contributed to microcytosis in at least $20 \%$ of this Gujarati Asian population, and there was biochemical evidence that the overall incidence of iron deficiency may have been even higher. These findings are similar to those of studies in Asian populations from several parts of the country that include various different ethnic and socioeconomic groups. ${ }^{2} 7 \mathrm{By}$ contrast only $5 \%$ of the European children had microcytosis caused by iron deficiency. It has been assumed that the iron deficiency is dietary in origin with a vegetarian diet being commoner among Asian than European children. It seems likely that the high incidence of iron deficiency in the children under 3 years of age results from the combined effect of an inadequate vegetarian weaning diet and the eating pattern of toddlers. The tendency of some parents to give their children large volumes of milk often into the third year of life may also be a factor.

In view of the evidence of an association between iron deficiency and delayed psychomotor development, it is important to detect and treat iron deficiency in this group. Simple screening tests for iron deficiency (for example, measurements of haemoglobin and mean corpuscular volume) may, however, be misleading: many of the children with microcytosis and confirmed iron deficiency had haemoglobin concentrations $>110 \mathrm{~g} / \mathrm{l}$ (fig 2 ), and the presence of microcytosis did not necessarily indicate iron deficiency. Furthermore, it is likely that a number of the non-microcytic children with biochemical evidence of iron deficiency would also have responded to oral iron. Quite apart from these problems of diagnosis, an appreciable number failed to take the iron supplements regularly; even with enthusiastic support, from health visitors, there was difficulty in getting some parents to give medicine to their children reliably. Dietary manipulation may be hard in this age group, and iron preparations are unpalatable.

$\alpha$ and $\beta$ thalassaemia traits each had an incidence of $4 \%$ in this population, representing 16 of the 76 children with microcytosis $(21 \%)$ and coexisted with iron deficiency in six cases. As children whose mean corpuscular volume on the first blood sample was $>74 \mathrm{fl}$ were not investigated further, some children with deletional $\alpha$ thalassaemia trait are likely to have been missed, as there is an overlap with the normal range for mean corpuscular volume. ${ }^{4}$ There may also be children with non-deletional $\alpha$ thalassaemia who were not detected by gene mapping.

In the current climate of enthusiasm for screening and treatment of iron deficiency, some children with microcytosis and a thalassaemia trait will inevitably be given unnecessary treatment with oral iron. It will therefore be important to avoid prolongation of such treatment in suspected iron deficiency without monitoring of the response by repeated blood counts: where the response is poor, additional tests will be required, including measurement of $\mathrm{HbA}_{2}$ and iron values. It is known that the accuracy of diagnosis of iron deficiency increases with multiple measures of iron status. ${ }^{11} 19$ Such measures are unlikely to be available in routine clinical practice, however, and it is therefore of interest that in this study increased values for serum total iron binding capacity appeared to be more sensitive in detecting reduced iron stores in microcytic Asian children than reduced concentrations of serum ferritin (fig 3).

We thank Dr D R Higgs of the MRC molecular haematology unit, John Radcliffe Hospital, Oxford, for carrying out $\alpha$ globin gene mapping. We also thank the staff of the haematology department, Northwick Park Hospital, for carrying out blood counts and $\mathrm{HbA}_{2}$ analyses, and the department of chemical pathology for measurements of serum iron and total iron binding capacity. We thank the staff of child health clinics in Harrow, and Nurses $R$ Nangia and $L$ McQuaid for help with blood sampling. The work was supported by a grant from Duncan Flockhart and Co Ltd. 
1 Isaacs D, Altman DG, Valman HB. Racial differences in red cell indices. F Clin Pathol 1986;39:105-9.

2 Ehrhardt $P$. Iron deficiency in young Bradford children from different ethnic groups. Br Med f 1986;292:90-3.

3 Addy DP. Happiness is: iron. Br Med f 1986;292:969-70.

3 Addy DP. Happiness is: iron. BrMed F 1986;292:969-70. Oxford: Blackwell, 1981 .

5 Anonymous. Iron deficiency - time for a community campaign. Lancet 1987;i:141-2.

6 Oski FA, Honig AS, Helm B, Howanitz P. Effect of iron therapy on behaviour performance in non-anaemic, iron deficient infants. Pediatrics 1983;71:877-80.

7 Aukett MA, Parks YA, Scott PH, Wharton BA. Treatment with iron increases weight gain and psychomotor development. Arch Dis Child 1986;61:849-57.

8 Lozoff B, Brittenham GM, Wolf AW, et al. Iron deficiency anaemia and iron therapy effects on infant development performance. Pediatrics 1987:79:981-95.

9 Deinard AS, Schwartz S, Yip R. Developmental changes in serum ferritin and erythrocyte protoporphyrin in normal (non-anemic) children. Am $\mathcal{f}$ Clin Nutr 1983;38:71-6.

10 Parks YA, Aukett MA, Murray JA, Scott PH, Wharton BA. Mildly anaemic toddlers respond to iron. Arch Dis Child 1989;64:400-1.

11 Koerper MA, Dallman PR. Serum iron concentration and transferrin saturation in the diagnosis of iron deficiency in children: normal developmental changes. $\mathcal{f}$ Pediatr 1977;91:870-4.

12 Koerper MA, Mentzer WC, Brecher G, Dallman PR. Developmental changes in red blood cell volume: implicaDevelopmental changes in red blood cell volume: implica-
tions in screening infants and children for iron deficiency tions in screening infants and children for iron deficis

13 Bainton DF, Finch CA. The diagnosis of iron deficiency anaemia. Am $\mathcal{J}$ Med 1964;37:62-70.

14 Price CP, Spencer K, Whitcher J. Light scattering immunoassay of specific proteins. Ann Clin Biochem 1983; 20:1-14.

15 Marengo-Rowe AJ. Rapid electrophoresis and quantitation of haemoglobin on cellulose acetate. F Clin Pathol 1965;18: $790-2$.

16 Old JM, Higgs DR. Gene analysis. In: Weatherall DJ, ed. Methods in haematology. London: Churchill Livingstone, 1983:74.

17 Weatherall DJ, Clegg JB, Na-Nakorn S, Wasi P. The pattern of disordered haemoglobin synthesis in homozygous and heterozygous-thalassaemia. Br 7 Haematol 1969:16: 251-67.

18 Higgs DR, Old HM, Pressley L, Clegg HB, Weatherall DJ. A novel alpha-globin gene arrangement in man. Nature
$1980 ; 284: 632-5$.

19 Cook JD, Fir

of of a population. Blood 1976;48:449-55. 